\title{
ADAT SEGULAHA DALAM TRADISI MASYARAKAT KESULTANAN TERNATE
}

\author{
Sagaf S. Pettalongi \\ STAIN Datokarama Palu \\ Jl. Diponegoro No.23 Palu Sulawesi Tengah. Telp. 081341197679 \\ email: bakungs67@yahoo.com
}

\begin{abstract}
Segulaha custom was a process of establishment and implementation of Ternate sultanate custom which was always obeyed and implemented by all the people of Ternate sultanate from the past time. The establishment of a custom was a joint agreement which becomes a guidance in managing socialization in all aspects for the interest of human prosperity. In implementing a custom, Ternate sultanate used bobato dunia system and bobato akhirat system as the organizer and director of custom convention/regulation and religious custom law. The major foundation of implementing segulaha custom began from se atorang custom, se kabasarang rules, galib se lukudi, ngare se cara sere se doniru and cing se cingari. Segulaha custom was implemented especially for joko kaha ceremony (injak tanah), crownprince coronation ceremony, sultanate inauguration ceremony (jou khalifah, jou kolano), and sultanate death ceremony. Segulaha custom was a form of combining of Islamic religious values and Ternate sultanate cultural values. Both values were integrated into one system of value which was sublimized by all people of Ternate sultanate North Maluku. Until this day, segulaha custom still implemented by the people of Ternate sultanate from generation to generation in cultural events.
\end{abstract}

Adat segulaha adalah proses pembentukan dan pelaksanaan adat kesultanan Ternate yang sejak masa lampau selalu ditaaati dan dilaksanakan oleh segenap masyarakat kesultanan Ternate. Terbentuknya suatu adat istiadat merupakan kesepakatan bersama untuk dijadikan pedoman dalam mengatur pergaulan hidup di segala bidang guna mencapai kebahagiaan manusia. Dalam pelaksanaan adat istiadat kesultanan Ternate dikenal dengan sistem bobato dunia dan bobato akhirat sebagai pengatur dan pengarah undang-undang adat 
dan hukum adat agama. Dasar utama pelaksanaan adat segulaha bersumber dari adat se atorang, Istiadat se kabasarang, galib se lukudi, ngare se cara sere se doniru dan cing se cingari. Adat segulaha dilaksanakan terutama pada upacara joko kaha (injak tanah), upacara pengangkatan putra mahkota, upacara penobatan Sultan (jou khalifa jou kolano), dan upacara kematian sultan. Adat segulaha merupakan bentuk perpaduan antara nilai-nilai agama Islam dan nilai-nilai budaya kesultanan Ternate. Keduanya terintegrasi dalam satu sistem nilai yang dijunjung tinggi oleh segenap masayarakat kesultanan Ternate Maluku Utara. Sampai saat ini adat segulaha masih tetap dilaksanakan oleh masyarakat kesultanan Ternate secara turun temurun terutama dalam acara-acara kebudayaan.

Key words: Custom, Segulaha, Ternate

\section{Pendahuluan}

Kesultanan Ternate merupakan salah satu kerajaan Islam tertua dikawasan Indonesia Timur terletak di sebelah utara kepulauan seribu pulau (Maluku), yaitu di pulau Ternate ibukota provinsi Maluku Utara. Kesultanan Ternate berdiri pada tahun $1257 \mathrm{M}$ dengan raja (kolano) pertama bernama Baab Mansur Malamo. Kesultanan Ternate memiliki peran penting di kawasan timur nusantara antara abad ke-13 sampai abad ke-17 M dan mengalami puncak kejayaannya sekitar abad ke-16 $\mathrm{M}$ berkat perdagangan rempah-rempah dan kekuatan militernya (Amal, 2005: 25). Pada masa kejayaannya pernah berkuasa meliputi wilayah Maluku, Sulawesi Utara, Sulawesi Timur dan Tengah serta sampai ke bagian selatan kepulauan Filipina hingga kepulauan Marshall di Pasifik. Sejak awal berdirinya kerajaan Ternate, masyarakatnya telah mengenal Islam mengingat banyaknya pedagang Arab yang tinggal menetap di Ternate waktu itu. Pada masa kekuasaan raja Zainal Abidin (1486-1500 M) untuk pertama kalinya istilah raja (kolano) diganti dengan sebutan sultan. Bahkan Islam diakui sebagai agama resmi kerajaan dengan memberlakukan syariat Islam serta membentuk lembaga kerajaan sesuai hukum Islam (Hasan, 1987: 19). Sejak masa itu kesultanan Ternate berkembang dengan nuansa syariat dan budaya Islam.

Dalam pelaksanaan adat kesultanan Ternate dikenal dengan sistem bobato dunia dan bobato akhirat sebagai pengatur dan pengarah undang-undang adat dan hukum adat agama. Bobato dunia artinya bagian yang mengatur hal ihwal kepentingan dan pengurusan keduniaan meliputi; komisi ngaruha yaitu yang diberi tugas tertentu sebagai lembaga eksekutif, serta komisi kapita yaitu lembaga pemerintahan yang bergerak dalam bidang kemiliteran. Adapun bobato 
akhirat yaitu lembaga yang mengatur tentang pelaksanaan yang menyangkut dengan kepentingan agama Islam yang terdiri dari: (1) jo kalem (qadhi), (2) imam terdiri dari imam Jiko, imam Jawa, imam Sangaji, imam Moti dan imam Bangsawan, (3) khatib terdiri dari khatib Jiko, khatib Jawa, khatib Sangaji, khatib bangsawan dan khatib Jo tulis dan (4) modim (Mudafar, tt: 17-18).

Adat segulaha yang merupakan cerminan integrasi nilai-nilai agama dan budaya dalam kehidupan sosial masyarakat Ternate, adalah sesuatu yang menarik untuk diteliti, karena sejak masa kekuasaan raja-raja kesultanan Ternate sebagai sebuah pemerintahan otonom hingga meleburnya ke dalam Negara Kesatuan Republik Indonesia (NKRI) bahkan sampai pada masa reformasi sekarang ini, masyarakat asli keturunan Ternate masih tetap melestarikan adat segulaha sebagai salah satu aturan dasar, pedoman dan pengaturan tata nilai dalam kehidupan sosial kemasyarakatan orang-orang asli suku Ternate. Untuk mengetahui sejauhmana pelaksanaan sistem adat tersebut, peneliti melakukan kajian terhadap adat segulaha dalam tradisi masyarakat kesultanan Ternate. Kajian dilakukan dalam pendekatan kualitatif dengan mengintegrasikan nilai-nilai agama dan budaya. Metode pengumpulan data dilakukan melalui wawancara dan studi dokumentasi serta literatur yang terkait dengan adat segulaha dalam masyarakat kesultanan Ternate. Data dianalisis dengan menggunakan anjuran Milies dan Huberman yakni reduksi, display dan verifikasi data serta analisis konten (content analysis) yakni menganalisis pelaksanaan adat istiadat masyarakat kesultanan Ternate dalam berbagai bentuk tradisi upacara adat (Miles dkk, 1992: 16-19).

\section{Kerangka Dasar Sumber Adat Istiadat Kesultanan Ternate}

Adat adalah sebuah aturan yang lazim diikuti atau dilakukan sejak dahulu kala (Poerwadarminta, 1989: 15). Adat biasa juga disebut kearifan lokal yaitu semua bentuk pegetahuan, keyakinan, pemahaman atau wawasan serta adat kebiasaan atau etika yang menuntun perilaku manusia dalam kehidupan di dalam komunitas ekologis. Atau dapat juga berupa kebenaran yang telah mentradisi atau ajeg dalam suatu daerah (Keraf, 2010: 35). Sedangkan kata segulaha adalah sebuah istilah yang berasal dari bahasa Ternate artinya membuat, melaksanakan (Rajiloen, 1983: 11). Maksudnya aturan yang lazim digunakan dan dilaksanakan untuk membentuk dan melaksanakan adatnya. Jadi adat segulaha bermakna pembentukan dan pelaksanaan adat kesultanan Ternate yang sejak dahulu kala hingga sekarang selalu diikuti dan ditaati masyarakat atau pengikutnya. Dalam hal ini adalah masyarakat bekas Kesultanan 
Ternate yaitu masyarakat keturunan asli Ternate yang mayoritas mendiami daerah kepulauan Ternate Maluku Utara, dan secara turun temurun masih setia melaksanakan adat istiadat kesultanan Ternate yang telah diwariskan oleh leluhurnya sejak masih aktifnya kerajaan kesultanan Ternate, bahkan sampai sekarang sebagian besar masyarakat asli Ternate masih mengakui dan melestarikan tata cara adat istiadat kesultanan Ternate dalam berbagai kehidupan sosial dan budayanya.

Pelaksanaan adat segulaha pada kesultanan Ternate bersumber pada lima kerangka dasar sebagai sumber dari adat istiadatnya, yaitu: (1) adat se atorang, (2) istiadat se kabasarang, (3) galib se lukudi, (4) ngare se cara sere se doniru dan (5) cing se cingari. Kelima sumber dasar tersebut diuraikan sebagai berikut:

1. Adat se atorang adalah hukum dasar yang bersumber pada al Quran al Karim dan sunnah rasulullah yang merupakan warisan yang ditinggalkan oleh Nabi Muhammad SAW. Sesuai dengan sabdanya:

"Kutinggalkan kepadamu (umat Islam) dua hal, apabila kamu berpegang teguh kepadanya, niscaya kamu tidak akan sesat selamanya, yakni al Quran dan Sunnahku" (HR Imam Malik).

Hukum dasar ini merupakan tolak ukur dalam pelaksanaan adat istiadat, yang menunjukan kesadaran dan keinginan bersama berdasarkan musyawarah sebagai sumber untuk meletakkan dasar-dasar hukum. Kepada yang bukan beragama Islam berlaku hukum tersendiri, sesuai dengan tata cara hidup bagi kelompok atau soa atau marga. Apabila dalam menetapkan adat istiadat yang dijadikan sebagai pegangan pergaulan hidup, terlebih dahulu dilakukan musyawarah sebagaimana dalam syariat Islam yang merupakan kunci kesuksesan dalam menyelesaikan segala macam masalah. Al Quran menyebutkan "Dan hendaklah kamu bermusyawarah dalam memutuskan suatu masalah atau perkara”(QS Ali Imran: 159).

Sebagai agama yang memberikan norma-norma tentang kehidupan sosial kemasyarakatan, Islam dapat berfungsi sebagai konsepsi budaya dan juga sebagai realitas budaya (Koentjaraningrat, 1981: 170). Artinya sumber dasar ajaran Islam al Quran dan al hadits tidak saja diterima menjadi sumber dasar nilai-nilai agama tetapi juga dapat menjadi sumber nilainilai budaya.

2. Adat istiadat se kabasarang adalah hak kekuasan dan hak kolano atau sultan yang mempunyai status kehormatan, gelar, mahkota, istana, dan hak veto yang disebut jaib kolano. Sebagai amir atau sultan, masyarakat harus menghormati dan mentaati segala perintah yang dititahnya, segala 
perintah dilaksanakan atas dasar kebenaran yang dijiwai ajaran Islam. Al Quran sangat menghargai keberadaan seorang pemimpin, terutama pemimpin yang dapat menuntun dan mengarahkan masyarakatnya kepada nilai-nilai kebenaran. Al Quran menyebutkan "Taatlah kamu kepada Allah dan rasul-Nya dan taat pula kamu kepada pemimpinmu"(QS an Nisa: 59).

Adat se kabasarang mengisyaratkan bahwa seorang pemimpin harus dapat dihargai dan dipatuhi karena keadilan dan kearifannya di dalam memimpin masyarakat, mereka juga bertanggung jawab atas jalannya pemerintahan negara. Pada masa lampau pemimpin atau raja dianggap sebagai tetesan para dewa, karena itu pemimpin harus teguh pendiriannya, bermental baja dan punya keyakinan yang kokoh (Agus, 2009: 72). Perilaku pemimpin atau raja pada masa itu menjadi panutan utama rakyatnya, jika pemimpin dan para bangsawan menerima agama baru, rakyat juga akan siap mengikuti, karena dalam adat mereka, dalam tingkat yang berbeda-beda, para raja atau sultan dipandang sebagai wakil dari Tuhan di dunia (Tjandrasasmita, 1996: 24).

3. Adat galib se lukudi adalah hak asal usul dan hak asasi atau hak dan kedudukan soa atau marga menurut asal usulnya, yakni kesamaan dan kesetaraan dalam pemenuhan hak dan kewajiban seseorang sesuai status sosial, baik sebagai pemimpin pegawai kerajaan maupun masyarakat biasa. Pemenuhan hak dan kewajiban masyarakat dilakukan sesuai status sosialnya dalam masyarakat, misalnya kalangan pejabat kerajaan diberi penghormatan oleh masyarakat berdasarkan soa atau marga yang disandangnya, demikian juga hak-hak lainnya seperti pemberian rumah tanah dan lainnya oleh sultan (Sulaiman, 1995: 45). Adat galib se lukudi mengisyaratkan bahwa hak pribadi seseorang, dan hak atas orang lain patut dihargai dan dijunjung tinggi menurut kebiasaannya, demikian pula hak cocatu artinya hak sultan dalam pemberian atas rumah-rumah, kebun untuk pribadi seorang pejabat kerajaan dan atau kepada soa yang bekerja pada kerajaan. Ada pula hak seseorang diluar soa yang kemudian diterima menjadi anggota soa atas dasar ikatan perkawinan, keahlian dan ilmu pengetahuan yang dimiliki.

4. Adat ngale se cara sere se doniru ialah kebiasan-kebiasaan yang baik dan berguna dalam menjaga kerukunan hidup bersama, sepanjang tidak bertentangan dengan hukum-hukum yang berlaku seperti: tata cara perkawinan, tata cara upacara adat dan tata cara pergaulan kerukunan hidup bermasyarakat. Sebagian besar ulama sependapat bahwa adat istiadat sebagai landasan dalam pembentukan hukum Islam, dan hukum Islam 
yang dibentuk berdasarkan pada adat istiadat akan bertahan selama adat masih dipertahankan oleh suatu masyarakat. Jika adat istiadat telah berubah maka kekuatan hukumnya pun akan berubah (Ali, 2008: 8). Adat ngale se cara sere se doniru yang telah disepakati dan berlaku dalam upacara-upacara adat kesultanan Ternate telah berlaku sejak masa kerajaan Ternate masih berkuasa penuh hingga sekarang setelah melebur ke dalam Negara Kesatuan Republik Indonesia, masih tetap dilestarikan dan dipegang teguh secara turun temurun.

5. Adat cing se cingari adalah kepatuhan/kedisiplinan dan ketaatan kepada hukum yang berlaku, diantaranya adalah tata tertib dan penampilan seseorang di depan umum berdasarkan soa atau marga yang disandangnya dalam setiap upacara kerajaan, serta mantaati status dan kedudukan soa itu sendiri, memelihara adat istiadat dalam pergaulan sehari-hari; tidak berbangga diri karena kedudukan dan jabatan, bersifat amanah dan rasa tanggung jawab atas tugas yang dipercayakan. Semua hal ihwal tersebut merupakan cerminan dan watak, serta sifat pembawaan dari rakyat moloku kie raha yang memiliki keramah-tamahan. Masyarakat yang menganut adat istiadat tertentu pada umumnya sangat taat terhadap setiap ketentuan-ketentuan yang bersumber dari adat istiadat, apapun status dan kedudukannya dalam masyarakat (kerajaan) sebab bagi yang membangkang akan terisolasi dari masyarakat lainnya (Sulaiman, 2001: 79). Artinya dari aspek sosiologis masyarakat terutama yang masih memegang teguh adat istiadat tertentu (masyarakat pedesaan) pada umumnya mereka lebih cenderung mentaati hukum-hukum adat yang berlaku daripada hukum negara dan agama. Dengan demikian kearifan lokal (local wisdom) pada setiap daerah perlu terus di jaga dan dilestarikan sebagai bentuk khazanah bangsa Indonesia dalam membangun karakter bangsa.

Kelima kerangka dasar tersebut di atas merupakan sumber adat istiadat yang telah dibudayakan sejak terbentuknya pemerintahan "Moloku" dalam hal ini zaman Islam moloku kie raha sampai sekarang.

Eksistensi adat dalam suatu masyarakat mempunyai fungsi tersendiri yakni selain sebagai pedoman dalam pergaulan hidup juga berfungsi sebagai hukum. Kedua fungsi ini dijadikan sebagai pengatur dalam pergaulan hidup manusia yang berlaku secara umum bukan dilakukan atau dikhususkan kepada golongan masyarakat tertentu saja. Baik sebagai penguasa, bawahan, maupun kalangan rakyat jelata, semuanya mempunyai hak yang sama dalam melaksanakan adat istiadat, sebab lahirnya suatu adat istiadat yang dijadikan sebagai hukum adat adalah atas kehendak bersama. Dengan demikian jelas sekali bahwa keberadaan adat istiadat adalah untuk mengatur pergaulan 
hidup di segala bidang guna mencapai kebahagiaan manusia. Tujuannya untuk menyelenggarakan kehidupan masyarakat yang aman, tenteram, dan sejahtera, maka dasar utama hukum adat adalah kesepakatan bersama antara masyarakat terhadap sesuatu nilai dan norma-norma tertentu sehingga itu hukum adat dijadikan sebagai salah satu sumber hukum dalam hukum Islam (Ali, 2011: 210).

Dalam falsafah hukum adat Ternate mengatakan: "jou se ngofa ngori”, yang secara maknawi berarti "engkau" artinya penguasa dan "aku" adalah rakyat. Maksudnya apa yang ada pada engkau, ada pada aku, dan sebaliknya apa yang ada pada aku ada pada engkau, atau dengan kata lain adat istiadat sebagai hukum adat harus membela kepentingan individu dengan tidak merugikan kepentingan bersama dan sebaliknya membela kepentingan bersama dengan tidak merugikan kepentingan individu. Itulah sebabnya dalam pelaksanaan adat istiadat kesultanan Ternate dilakukan secara bersama menurut hak dan kedudukan sesuai dengan soa atau marga dalam tugasnya.

\section{Pelaksanaan Upacara Adat Segulaha Masyarakat Kesultanan Ternate}

Pelaksanaan adat kesultanan Ternate mempunyai sistem tersendiri yang diatur pelaksanaannya oleh bobato dunia dan bobato akhirat. Keduanya berfungsi untuk mengatur undang-undang adat dan hukum adat agama. Ada beberapa bentuk upacara adat yang perlu diketahui menyangkut dengan pelaksanaan adat kesultanan Ternate, antara lain:

1. Upacara joko kaha (injak tanah)

Joko kaha adalah salah satu upacara tradisional yang dilaksanakan pada penerimaan tamu agung bagi seseorang yang baru pertama kali menginjakkan kaki di bumi Ternate moloku kie raha. Tanahnya diambil sebagian, diletakkan dalam piring, kemudian diinjak. Dalam upacara ini ditujukan untuk acara-acara kenegaraan, dengan menampilkan empat orang putra disebut "ngongare" dan empat orang putri yang disebut "jojaro". Keempat orang putra putri melambangkan empat orang sultan dalam wilayah moluku kie raha. Materi upacara joko kaha terditi dari: (a) satu piring kecil berisi segenggam tanah, mengandung makna bumi, bukit dan gunung, (b) serumpun rumput yang disebut fortage mengandung makna rimba belantara, (c) satu botol air mengandung makna danau-danau, telaga serta sungai-sungai dan lautan, (d) bunga rampai mengandung makna keharuman budi pekerti rakyat Ternate, (e) beras populek (beras berwarna putih, kuning, merah,hitam), melambangkan semangat bhineka tunggal ika rakyat Maluku Utara yang terdiri dari berbagai suku (Depdikbud, tt: 95). Kelima 
macam materi upacara tersebut tidak pernah berubah sepanjang masa, hanya upacara joko kaha yang dilaksanakan untuk upacara kenegaraan ataupun acara resmi, ditambahkan lagi dengan sehelai kain putih yang dihamparkan. Kain putih tersebut melambangkan kemurnian alam Maluku Utara (Museum, 1992: 20). Upacara joko kaha adalah bentuk penghormatan kepada tamu yang datang ke Ternate terutama pemimpin-pemimpin negara atau kerajaan. Cermin budaya ini menunjukan bahwa upacara adat injak tanah (joko kaha) adalah salah satu bentuk refleksi religiusitas masyarakat Ternate, sebab dalam Islam menghormati tamu adalah termasuk perbuatan mulia. Hal ini tampaknya sejalan dengan konsepsi agama dalam perspektif sosiologis yakni sebuah sistem nilai yang memuat sejumlah konsepsi mengenai konstruksi realitas yang berperan besar dalam menjelaskan struktur tata normatif dan tata sosial serta memahamkan dan menafsirkan dunia sekitar, sementara tradisi merupakan ekspresi cipta, karya dan karsa manusia (dalam masyarakat tertentu) yang berisi nilai-nilai dan pesan-pesan religiusitas, wawasan filosofis dan kearifan lokal (Kuntowijoyo, 2001: 196). Agama maupun kebudayaan, keduanya memberikan wawasan dan cara pandang dalam menyikapi kehidupan agar sesuai dengan kehendak Tuhan dan kemanusiaan.

2. Upacara Pengangkatan Putra Mahkota.

Apabila sultan hendak menunjuk atau mengangkat salah seorang putranya menjadi putra mahkota yang di sebut "ngofa majojo" terlebih dahulu berkonsultasi dengan kepala pemangku adat istana dan kepala pemangkut agama istana. Meskipun biasanya putra mahkota itu adalah putra sulung namun apabila putra sulung tersebut karena sesuatu hal tidak dapat diangkat menjadi putra mahkota karena sesuatu kekurangan misalnya kurang cakap atau karena putra sulung berbuat sesuatu yang melanggar adat istiadat istana maka diperlukan adanya musyawarah atau konsultasi dengan para pemangku adat istana dan pemangku agama istana.

Apabila sudah dicapai kata sepakat barulah diberi tahu kepada pangeran untuk mempersiapkan diri guna disahkan pengangkatannya sebagai putra mahkota (ngofa majojo). Upacara ini di hadiri sultan, permainsuri dan seluruh keluarga, para raja fazal dan para duta besar negara asing. Juga dihadiri oleh perdana menteri, para menteri serta dewan perwakilan yang mewakili delapan belas soa. Sultan duduk di atas tahta, lalu pengeran yang bersangkutan datang duduk di lantai menghadap sultan, dengan sikap bersembah, lalu sultan mengucapkan titahnya. Dan sejak itu pengeran tadi menjadi ngofa majojo atau putra mahkota. Kemudian putra mahkota mengucapkan janji akan 
setia kepada sultan, negara, agama dan adat. Setelah itu lalu dibacakan doa untuk keselamatan putra mahkota oleh para imam istana (Depdikbud, tt: 96). Tradisi pengangkatan putra mahkota dalam raja-raja di nusantara adalah tradisi umum yang telah ada sebelum Islam tetapi setelah Islam masuk ke Indonesia dan menjadi agama kerajaan tertentu, maka proses pengangkan putra mahkota kemudian memadukan nilai agama dan budaya setempat (Sewang, 2005: 125).

\section{Upacara Penobatan Sultan (jou khalifa jou kolano)}

Seminggu sebelum putra mahkota dinobatkan menjadi sultan dalam sebuah upacara kenegaraan, ia harus menjalani adat mengurung diri. Adat mengurung diri mengandung makna filosofis yaitu untuk mensucikan kepribadian lahir batin. Dengan disaksikan oleh segolongan para anggota keluarga istana, perdana menteri atau jogugu, para menteri atau seluruh peserta anggota dewan perwakilan rakyat, para tetua, para kepala soa, para ulama, qhadi, imam, khatib, modim, para raja, fazal, para duta besar negara-negara asing, putra mahkota duduk di tahta. Kemudian Kepala soa, kimalaha marsaoli sebagai Ketua Dewan Rakyat, dengan didampingi oleh kepala pemangku adat istana dan kepala pemangku agama istana melangkah ke depan untuk memberikan penghormatan (sembah). Lalu dua orang petugas khusus yang disebut sowohi dan sodaha membawa mahkota (stampa) menghampiri tahta dan mengenakan ke kepala putra mahkota. Sejak detik itulah putra mahkota menjadi sultan jou khalifa, jou kolano, diiringi doa oleh mufti serta lima imam Istana (imam Jiko, imam Jawa, imam Sangaji, imam Moti dan imam Bangsa). Pada saat itulah para tamu turun dari tempat duduknya untuk menghaturkan sumpah pengukuhan kepada sultan yang baru. Kemudian perdana menteri (jogugu) tampil kedepan berhenti beberapa langkah di depan sultan, menghaturkan sembah dan menyampaikan laporan (suba) khusus untuk upacara penobatan sultan. Laporan khusus tersebut disampaikan dengan mempergunakan bahasa yang berirama (rorasa). Teks langkah laporan khusus yang berbahasa Ternate, dalam upacara penobatan sultan yang pertama hingga sultan yang terakhir telah berlangsung selama 7 abad mulai dari tahun 1257 M-1930 M adalah sebagai berikut:

Sailillah suba jou kolano lamo-lamo no khalifah ma gori-gori. Sailillah suba jou kolano lamo-malo no khalifah ma gori-gori. No khalifah fat ur Rasyid, no tubaddilur Rasul.

No gugu tadbir parentah amar se nahi toma alam daerah moloku istana baldan Ternate, no tego toma singgasaan kolano, ni jojoko no sijoko toma thinil molok, nimomina se ni gogise mangagu ngagu intan se yakutmalili parmata jamrut, 
ma bobela ratna mut jauhar manikam, ma cahaya isi woro toma alam daerah moloku istana bandan Ternate, limau duko se gapi, gapi se seki, matubu la ida di ka cahaya akal ihsan kolano.

Sailillah suba jou kolano lamo-lamo no khalifah ma gori-gori.

Kum kum uwa majo ni so syusyu kone rasul wajir fangare jogugu he Abdul Habib jiko tu tede re suba paksan mangale to siwaje waje ni molok kie raha Ternate se Tidore, Bacan se Jailolo, Sema mie gudu-gudu tobuku se Banggai se masara gudu gudu Sula se Taliabo se ni ronga se ni bobato dunia se akhirat, Soa sio se sangaji, Heku se Cim, se ni bangsa bara bangsa se ningofa ngofa kolano, se ningofaangare pehak berpehak se ni agama rasulullah maje jaga jokalem, se jo imam se jo khatib bobula raha, se nibala seni raayat, seni sahabat yang mukarram hoframintu Walandawi, ma istiadat sema kabasarang ma adat sema atoran, ma galib se malukudi, mengale sema cara, mangaro sema biasa, ngofangure ngommi mamoi moi mi hadir saddia tatap lengkap mi tede se misaha, misimulia se misidodoma toma zaman mtakaddimin se gado toma zaman mula akhiri itola ua moju toma safutu se wange isidutu hari kiamat.

Sailillah suba jou kolano lamo-lamo no khalifah ma gori-gori

Kum-kum uwa moju ni so syusyu ngofangare jogugu he Abdul Habib Jiko to tede suba paksan.

Upacara ini merupakan upacara kenegaraan yang terpenting dan terbesar (Depdikbud, tt: 96).

Pelaksanaan upacara-upacara adat senantiasa di tandai dengan bobato akhirat, seperti doa-doanya yang dibacakan oleh pemangku adat agama, untuk keselamatan manusia dalam kehidupannya. Untuk lebih jelasnya dapat dikemukakan seperti pada upacara joko kaha (injak tanah). Sebagai berikut :

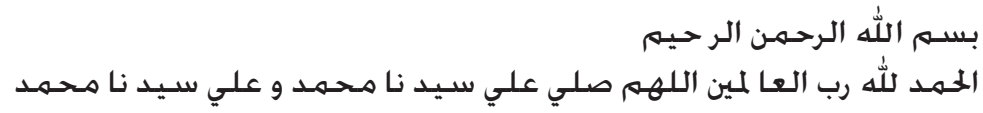

Ngofangare ngomronga bala se raarat moloku kie raha Ternate se Tidore, Bacan se Jailolo toma mie gudugudu sala se Tailabo. Misi tede mia puji se mia sukur sejou khalikul makhluk Rabbul arail adlim irahmati se ni' mati iduka se igogoru se toma wange enane.... ibu serta rombongan idoru mai ito, ijoko mie kaha, sengofangare ngom mima moi moi mi rubu rubu se rame rame, mitede se misaha, milego se misimore si milahi lahi do'an se jou Rabbul aalamin la segila I umur se kokoko I zaman toma dhahir se batin, si sehat si afiah I jasad, si fela I akal se ikira kira laosi gogoko hokum se perentah to maamara bil ma'ruf anahil munkari wayahkumul adilina baenar rijali wannisa, la osiogo malimau toma baldatun tahibatun wa rabban gafura.

La ngoni bala se ra'yat, kie se gam, midorusu maalo se marano, marajiki se marahmati, toma se toma nyina toma murah se toma gampang, toma sehat se afia toma sofutu se wange moso se lobi, toma daiman abadi.

Artinya: Dengan mengagungkan nama Allah Maha Pengasih dan 
Penyayang. Kami seluruh rakyat Maluku Utara mulai dari ujung morotai sampai ke ujung Taliabo, mempersembahkan puja dan syukur kehadirat Allah, Tuhan seru sekalian alam, atas rahmat dan karuniaNya , cinta dan kasih sayang-Nya pada hari ini ..... ibu serta rombongan, berkesempatan mengunjungi daerah, menginjak bumi kami, maka kami rakyat semua menyambut dengan hati yang penuh riang dan gembira, diliputi rasa untung dan bahagia.

Kami panjatkan doa kehadirat-Mu ya Tuhan, kiranya Kau penjatkan usianya, sehat afiatkan jasadnya, luaskan akal dan pikirannya, tanamkan jiwanya baik lahir maupun batin agar ia dapat menjalankan pemerintahan dan menegakkan keadilan mengajak kepada kebaikan dan mencegah kejahatan, berlaku adil baik kepada laki-laki maupun perempuan dan berikanlah kemampuan menenangkan daerah ini menjadi negeri yang aman damai dan makmur di bawah naungan rahmat-Mu ya Tuhan.

Semoga kami rakyat, daerah dan Negara, diliputi suasana aman dan damai, dilimpahkan rezeki dan rahmat di laut dan di darat, murah dan gampang, sehat dan afiah sepanjang masa siang dan malam, pagi dan petang tidak berkeputusan selama-lamanya (Proyek Pengembangan Media Kebudayaan, 1985: 79).

\section{Upacara Kematian Sultan}

Sudah menjadi adat di Ternate apabila sultan mangkat maka sebelum sultan yang baru dinobatkan terlebih dahulu dilakukan serangkaian upacara kematian. Jenazah sultan setelah dimandikan dan dibungkus dengan kain kafan kemuian disemayamkan di balai rumah istana menghadap ke kiblat. Sementara itu dikirim utusan untuk menjemput ayah dan ibu suri (jika masih hidup), serta memberitahukan kepada kepala suku soa marsaoly. Karena soa marasoly mempunyai tugas tradisional apabila ada sultan yang mangkat.

Para keluarga istana diwajibkan untuk mempersiapkan busana duka yang terbuat dari pandan yang akan dipakai bila mengantar jenazah sultan sampai ke makam. Juga tandu sultan yang biasa dinaiki raja dan dibawa ke masjid setiap hari jumat di selimuti dengan busana kematian sultan. Isteri kepala soa marsaoly dan para perempuan soa marsaoly mengenakan topi-topi yang bentuknya seperti kerucut. Kemudian para perempuan soa marsaoly itu bersama-sama mengelilingi jenazah dan serempak menangisinya. Kemudian para ulama, qadhi, para imam dan khatib bersama-sama shalat jenazah. Para pejabat tinggi, Gubernur atau Residen, Komandan Garnizum, para Raja Fazal serta para duta negara tetangga diberi kesempatan untuk memberi penghormatan terakhir kepada almarhum sultan. Sesaat sebelum jenazah di arak keluar dari istana terlebih dahulu diadakan upacara penghormatan secara militer (Proyek Pembangunan Media Kebudayaan, 1985: 56). Tradisi model ini 
hampir berlaku pada semua raja-raja di nusantara yang telah menerima Islam sebagai agama kerajaan atau setelah terjadinya Islamisasi kerajaan, meskipun ada juga beberapa perbedaan dari aspek budayanya berdasarkan kearifan lokal setiap daerah (Sewang, 2005: 136).

Melihat nilai-nilai dan tata cara pelaksanaan dari kedua sistem adat tersebut yaitu bobato dunia dan bobato akhirat, memberikan gambaran bahwa adat dan tradisi yang dilakukan dalam masyarakat kesultanan Ternate yang masih terlaksana sampai sekarang, merupakan perpaduan antara nilai-nilai agama dan budaya sebagai bentuk kearifan lokal masyarakat Ternate yang kemudian melahirkan suatu bentuk budaya Islam yang toleran. Nilai-nilai semacam ini merupakan kekayaan budaya yang bertumbuh kembang dalam sebuah masyarakat kemudian dipercayai dan diakui sebagai elemen-elemen penting yang mampu mempertebal kohesi sosial diantara warga masyarakat (Liliwere, 2003: 67). Nilai-nilai kearifan lokal adalah wujud kekayaan budaya yang perlu diangkat sebagai bentuk jati diri bangsa.

\section{Nilai-Nilai Yang Terkandung dalam Adat Segulaha}

Beberapa nilai-nilai yang terdapat dalam pelaksanaan adat istiadat kesultanan Ternate dapat dilihat dalam proses terbentuknya adat-istiadat tersebut, serta proses pelaksanaannya.

1. Masa proses terbentuknya.

Terbentuknya adat istiadat (segulaha), yang dijadikan sebagai lembaga adat dalam wilayah kesultanan Ternate, diperlukan adanya syarat yang harus dipenuhi antara lain : wilayah territorial, rakyat dan lembaga yang mengaturnya. Masyarakat pada saat itu hidupnya secara berkelompok dan belum dibentuk lembaga adat. Masyarakatnya antara lain terdiri dari ; tabona, tubo, tabanga dan toboleu. Tipe kehidupan masyarakat masih menetap di negara "Gapi" (sebuah sebutan kelompok masyarakat pertama asal usul masyarakat Ternate) sebagai masyarakat asli Ternate.

Langkah awal pembentukan adat telah dimulai pada tingkat soa atau marga. Dari sini pula pertama kali terbentuknya soa di Ternate pada tahun $1252 \mathrm{M}$, sampai sekarang soa tobona masih ada dengan kepala soa-nya disebut "fanyira" artinya orang yang tertua, begitu pun tubo, tabanga dan tobeleu, peninggalannya masih ada sampai sekarang. Kemudian dari sinilah mereka mengambil satu sikap untuk melangkah lebih jauh yakni dengan mempersatukan melalui musyawarah, atas dasar kesepakatan itulah diangkat salah seorang dari keempat kelompok masyarakat tersebut, yakni dari soa tobona yang bertempat 
di "Foramadiahi" dengan gelar baru "kolano" artinya orang yang diharapkan, selanjutnya dari sini kemudian menjadi kelompok konfiderasi dari keempat kelompok tersebut.

Sikap masyarakat dengan pimpinan yang baru (kolano), melahirkan galib se lukudi artinya adat istiadat. Mulai dari zaman kolano ini menjadi langkah awal untuk menuju kelengkapan aparat pemerintahan yang kemudian melahirkan pembentukan lembaga adat Ternate.

Sejalan dengan tumbuh dan berkembangnya masyarakat demikian pula dalam pergaulan kehidupan juga tumbuh dan berkembang dengan berbagai bentuk kegiatan yang terefleksi dalam kebiasaan-kebiasan berkumpul yang diadakan di negeri "Gapi" dan semua rakyat pulau "Gapi" yaitu keempat orang sultan moluku kie raha; (sultan Ternate, sultan Tidore, sultan Jailolo dan sultan Bacan), berkumpul dan bermusyawarah untuk membentuk lembaga adat bersama pada tahun $1257 \mathrm{M}$, yang merupakan lembaga adat tertinggi di moloku kie raha, guna menjadi pegangan dan pedoman bersama dalam proses interaksi kehidupan sosial dan kenegaraan. Hal itu merupakan aspirasi dan keinginan masyarakat untuk melanjutkan hidup dalam bentuk "gameinschaft" yang disusun berdasarkan lima kerangka dasar sebagai sumber adat sebagaimana dijelaskan sebelumnya. Sebab tumbuh dan berkembangnya masyarakat menuntut adanya keteraturan moral dari kehidupan sosial, maka harus mempertimbangkan adanya aturan sosial yang ditetapkan oleh masyarakat dan aturan prosedural untuk mengatur kenyataan sosial (Sidik, 2011: 53). Keteraturan social pada dasarnya adalah keteraturan masyarakat yang diatur berdasarkan aturan-aturan nilai dan moral. Dalam masyarakat tidak hanya sekedar suatu penjumlahan individu semata melainkan menampilkan suatu realita tertentu yang mempunyai ciri-cirinya sendiri dengan berbagai karakter dan keunikannya (Barry, 1982: 5). Atas dasar prinsip-prinsip dan realita sosial itu kemudian masyarakat membangun kesepakatan norma dan nilai-nilai sebagai pegangan bersama yang berbentuk adat istiadat (Hartono dkk, 1997: 68).

Dengan uraian di atas tampak bahwa sejak awal keberadaanya kalangan masyarakat Ternate memiliki komitmen yang kuat dalam membentuk tatanan masyarakat yang damai, teratur dan toleran dengan membentuk sebuah adat istiadat sebagai pedoman dan pegangan dalam kehidupan sosial kemasyarakatan. Melalui adat istiadat itu diharapkan dapat mewujudkan kebersamaan dalam menjalankan adat, yang sebelumnya selalu didahului dengan mengadakan musyawarah, termasuk penetapan hukum adatnya. Syariat Islam menetapkan 
bahwa prinsip dasar dari pelaksanaan suatu kebijakan harus melalui musyawarah karena itu di tekankan dalam al Quran:

".... dan bermusyawaralah dengan mereka dalam urusan itu, kemudian apabila kamu telah membulatkan tekad, maka bertaqwlah kepada Allah. Sesungguhnya Allah menyukai orang-orang yang betawakkal kepada-Nya (QS al Imran: 159).

Sebagai perwujudan dari kerangka dasar adat istiadat pada masa proses terbentuknya adat segulaha telah memiliki dampak positif dikalangan kerajaan dan sultan, demikian juga masyarakat Ternate pada umumnya. Oleh karena yang menjadi jatidiri utama dalam kehidupan sosial adalah bagaimana mengembangkan kerukunan dan kebersamaan dalam melaksanakan adat dengan tidak membeda-bedakan soa atau marga dalam penerapannya.

2. Masa Proses pelaksanaannya

Setelah terbentuknya adat sebagai lembaga yang tertinggi di moloku kie raha, maka sebagai realisasi dari adat tersebut adalah mewujudkan kerukunan dalam kehidupan masyarakat dengan mengikuti tata aturan yang berlaku sesuai dengan kerangka dasar dari adat istiadatnya. Kebiasaan tradisional dijadikan sebagai acuan normatif sehingga ia menjadi adat yang diistimewakan. Hal tersebut menunjukkan sikap dan perilaku kehidupan individu maupun kelompok masyarakat dengan budaya yang dimilikinya.

Adat istiadat semasa pemerintahan kesultanan Ternate yakni dari Sultan pertama Cico alias Baab Masyur Malamo (1257 M) tidak jauh berbeda dengan apa yang dilaksanakan pada masyarakat karena adat kraton (adat Istana) merupakan pencerminan martabat tertinggi yang dijadikan teladan oleh masyarakat meskipun ada pula beberapa dari adat kraton yang tidak boleh ditiru atau dilaksanakan oleh masyarakat diluar kalangan istana seperti adat pernikahan keluarga raja atau sultan yang menempatkan jabatan dalam prosesi adatnya yang bersifat khusus. Selain adat istiadat yang khusus untuk diberlakukan bagi keturunan raja atau sultan, ada juga adat istiadat yang tidak bisa dilakukan oleh kesultanan maupun masyarakat luas karena dianggap bertentangan dengan nilai dasar ajaran Islam seperti dalam upacara kematian raja atau sultan yang cenderung dianggap bernuansa syirik. Sehingga pada masa pemerintahan sultan Muhammad Zain $(1824 \mathrm{M})$ beliau memerintahkan untuk dilakukan musyawarah adat guna membahas hal tersebut dengan melibatkan para pejabat tinggi kesultanan, para tetua adat, para kepala adat dan para ulama. Hasilnya memutuskan bahwa adat sesajian dalam upacara kematian raja atau sultan bertentangan dengan hukum Islam. Oleh karena itu beberapa bagian dari adat kesultanan dalam upacara kematian raja atau sultan tersebut dihapuskan, diantaranya adalah: (a) para tetua dan kepala 
adat tidak lagi dibenarkan melakukan penghormatan kepada orang yang telah meninggal seolah-olah ia masih hidup, (b) para isteri tetua adat, para kepala adat dan ketiga tingkat ngofa ngare jika melayat raja yang meninggal tidak lagi dibenarkan menggunakan busana duka yang tebuat dari daun pandan, (c) pada setiap upacara kematian raja atau sultan para perempuan tidak lagi dibenarkan menggunakan topi dan membawa piala emas dan hanya bisa dilakukan oleh para lelaki, (d) tidak lagi dibenarkan menyanyikan lagulagu dalam istana dan makam, (e) jika raja atau sultan wafat tidak perlu lagi menjemput kedua orang tua raja atau sultan yang biasanya dilakukan oleh dua orang kepala adat dan memberitahukan kepada kepala marsaoly serta isteriisterinya guna memberikan penghormatan dengan cara menangisi jenazah raja atau sultan baik di istana maupun di makam, (f) tandu dan kuda yang dinaiki raja lengkap dengan busana duka tidak perlu lagi dibawa ke makam, (g) setelah jenazah raja atau sultan dimakamkan tidak lagi dibolehkan membuat tempat kediaman roh raja atau sultan di istana (Proyek Pengembangan Media kebudayaan, tt: 103-104).

Proses terbentuknya adat istiadat serta tatacara proses pelaksanaan adat istiadat kesultanan Ternate seperti diuraikan di atas, tampaknya dibangun di atas kesepakatan bersama antara semua unsur yang ada dalam masyarakat kesultanan yang disebut dengan soa atau marga. Para soa atau marga inilah yang menyerap aspirasi dan nilai-nilai budaya yang tumbuh dan berkembang dalam masyarakat, kemudian ditetapkan sebagai aturan dan kesepakatan bersama untuk dipedomani dalam kehidupan sosial kemasyarakatan dibawah kendali kerajaan atau sultan. Corak adat kesultanan Ternate yang telah berlaku secara turun temurun sejak masa kesultanan Baab Mansyur Malamo (1257 M) hingga sekarang, merupakan perpaduan antara nilai agama dan budaya (kearifan lokal). Pertautan antara nilai agama dan realitas budaya dapat dimungkinkan terjadi karena agama tidak berada dalam realitas yang vakum-selalu original. Mengingkari keterpaduan agama dengan realitas budaya berarti mengingkari realitas agama sendiri yang selalu berhubungan dengan manusia, yang pasti dilingkari oleh budayanya (Geertz, 1981: 54).

Adat segulaha dalam tradisi masyarakat kesultanan Ternate mengandung beberapa nilai-nilai moral, sosial budaya dan agama yang dianut oleh masyarakat kesultanan Ternate yang teridentifikasi sebagai berikut: pertama, adat istiadat kesultanan Ternate telah diwariskan secara turun-temurun dari generasi ke generasi dan tetap berkembang meskipun orang yang menjadi anggota suatu masyarakat sudah silih berganti akibat kematian dan kelahiran tetapi 
nilai-nilai sosial budaya itu tetap berfungsi sebagai patokan dan pendorong perilaku masyarakat di dalam hidupnya.

Kedua, nilai-nilai etika dan moral yang terkandung dalam upacara joko kaha (injak tanah). Upacara ini merupakan puncak dari adat istiadat di moloku kie raha (khususnya Ternate), upacara tersebut dilaksanakan sebagai bentuk penghormatan terhadap tamu-tamu yang datang ke Ternate, khususnya tamutamu yang dihormati seperti pejabat, tetua adat, tokoh agama dan masyarakat. Tradisi ini memiliki nilai-nilai moral yang tinggi sebab setiap tamu yang datang diperlakukan secara baik dan terhormat, sekaligus memperlihatkan bentuk dan tata cara menerima tamu sesuai dengan adatnya bahkan sekaligus mempersatukan dan mempererat hubungan sesama manusia. Konsep ini selaras penegasan Rasulullah SAW dalam sabda-Nya:

"Barang siapa beriman kepada Allah dan hari akhir maka hendaklah ia memuliakan tamunya dan barang siapa yang beriman pada Allah dan hari akhir maka hendaklah ia berbuat baik kepada tetangganya dan barang siapa yang beriman kepada Allah dan hari akhir hendaklah ia berkata baik atau jika tidak hendaklah ia diam saja" (HR Imam Husain).

Konsep joko kaha ini merupakan bentuk implementasi dari nilai-nilai ajaran Islam dalam menyambut dan memuliakan tamu. Tata cara pelaksanaan upacara joko kaha ini tidak pernah berubah selama berabad-abad. Pelaksanaan upacara joko kaha tidak hanya sultan dan keturunannya tetapi setiap orang yang sedang menjalani suatu upacara adat dalam kehidupan sosial budaya masyarakat Ternate sampai pada saat ini masih tetap dilaksanakan.

Ketiga, nilai-nilai dalam adat istiadat perkawinan seperti nilai moral dan agama, nilai harga diri, serta nilai kegotong-royongan. Nilai moral dan agama, tampak dalam adat peminangan. Dalam adat peminangan yang bertindak sebagai juru bicara harus dari kalangan tokoh agama atau orang yang dituakan dan memahami agama Islam sebab dalam proses pembicaraan itu tidak jarang di dahului dengan petuah-petuah agama dari kedua bela pihak dengan mengemukakan beberapa ayat atau hadis. Demikian pula dalam tata cara menerima tamu, hingga selesainya acara perkawinan dilaksanakan secara adat, tamu-tamu yang bergelar haji diberi tempat dan kedudukan pada urutan paling depan dan terhormat dalam acara perkawinan tersebut.

Nilai harga diri, dalam adat istiadat perkawinan masyarakat kesultanan Ternate ditekankan bahwa jika seseorang sudah sanggup untuk menikah baik laki-laki maupun perempuan maka harus segera dilaksanakan sebab perkawinan akan dapat mengangkat derajat dan harga diri seseorang, karena dengan perkawinan ia bisa terhindar dari perilaku buruk dan maksiat serta 
dianggap menjadi sempurna ibadahnya sesudah menikah.

Nilai kegotong royongan, pada adat perkawinan masyarakat Ternate jika pihak laki-laki dan pihak perempuan sudah saling mencintai, maka kedua bela pihak benar-benar akan menunjukkan kerja sama dalam mewujudkan keinginan perkawinan itu melalui musyawarah bersama dengan kedua keluarga besar. Bahkan dari masing-masing pihak dapat menanggung bersama biaya perkawinan sehingga pelaksanan perkawinan dapat berlangsung dengan baik dan segera. Adat istiadat dan tradisi semacam itu masih dilestarikan sampai saat ini.

Adat istiadat dan beberapa nilai yang disepakati dan berlaku dalam kesultanan Ternate pada masa lampau hingga sekarang ini masih terus dilaksanakan baik oleh kalangan keturunan sultan Ternate maupun oleh kalangan masyarakat asli Ternate yang secara turun temurun sangat menghormati sultan berikut dengan segala bentuk pelaksanaan adat istiadatnya. Oleh karena itu adat istiadat yang tetap hidup dan berkembang di kalangan masyarakat Ternate, perlu terus dilestarikan sebagai suatu bentuk penghargaan atas kearifan lokal yang di dalamnya terkandung banyak nilai-nilai moral dan agama yang dapat berkontribusi positif dalam pembangunan peradaban dan kebudayaan bangsa, sekaligus sebagai bentuk relasi agama dan budaya secara positif-konstruktif. Relasi itu bermakna bahwa Islam sebagai ajaran yang normatif berasal dari Tuhan diakomodasikan ke dalam kebudayaan yang berasal dari manusia dengan tanpa kehilangan identitasnya masing-masing (Wahid, 2001: 111). Sebab pada prinsipnya semua warisan dan nilai budaya masa lampau perlu diapresiasi dengan baik karena keberhasilannya yang luar biasa, sekaligus juga perlu dicermati (Abdullah, 2000: 189).

Dalam sejarahnya interaksi agama dan adat istiadat yang telah membentuk suatu nilai-nilai tertentu, terjadi dengan tiga pola yaitu: (1) agama mempengaruhi budaya (adat) dalam pembentukannya, nilainya adalah agama tetapi simbolnya adalah kebudayaan (adat), (2) agama dapat mempengaruhi simbol agama, misalnya kebudayaan Indonesia mempengaruhi Islam dengan pesantren dan kiyai yang berasal dari padepokan, (3) kebudayaan (adat) dapat menggantikan sistem nilai dan simbol agama. Agama dan adat juga mempunyai dua persamaan yakni keduanya adalah sistem nilai dan sistem simbol (Sidik, 2011: 86). Agama adalah simbol yang melambangkan nilai ketaatan kepada Tuhan, adat (budaya) juga mengandung nilai dan simbol supaya manusia bisa hidup di dalamnya (Kuntowijoyo, 2001: 195). Namun demikian keduanya perlu dibedakan, yakni agama adalah sesuatu yang final, universal, abadi dan 
tidak mengenal perubahan (absolut), sedangkan kebudayaan (adat) bersifat partikular, relatif dan temporer. Agama tanpa kebudayaan memang dapat berkembang sebagai agama pribadi tetapi tanpa kebudayaan agama sebagai kolektifitas tidak akan mendapat tempat.

\section{Simpulan}

Kesultanan Ternate yang berdiri sejak tahun 1257 M dengan raja pertama bernama Baab Mansyur Malamo adalah salah satu kerajaan terbesar pada abad-abad 13-17 M. Kekuasaannya meliputi atas wilayah Maluku, Sulawesi Utara, Timur dan Tengah bahkan sampai ke Filipina selatan dan kepulauan Marshall Pasifik. Sebagai kerajaan Islam yang kuat pada masa itu dengan rajanya bergelar sultan telah memiliki akar budaya dan adat istiadat yang kuat, bersumber dari nilai-nilai agama Islam dan nilai-nilai budaya leluhur. Adat istiadat yang tumbuh dan berkembang di lingkungan masyarakat kesultanan Ternate ditaati dan dilaksanakan secara konsisten sampai sekarang ini.

Dalam tata cara dan prosesi pelaksanaan adat segulaha jika dilihat dari nilai ajaran Islam tampak bahwa adat istiadat masyarakat kesultanan Ternate sangat kental dengan nuansa keislaman disamping corak budayanya tetap merupakan nilai-nilai budaya leluhur masyarakat. Artinya dalam adat segulaha tampak terintegrasi di dalamnya antara unsur keislaman dan unsurunsur budaya. Adat segulaha dalam tradisi masyarakat kesultanan Ternate merupakan salah satu cerminan kearifan lokal masyarakat Indonesia yang telah diwariskan secara turun temurun hingga sekarang, dan telah berkontribusi penting dalam pengembangan masyarakat dan bangsa Indonesia terutama dalam pembentukan watak dan karakter masyarakat, sebab sumber utama dalam pembangunan dan pembentukan karakter adalah bersumber dari nilai-nilai ajaran agama dan nilai-nilai kearifan lokal (local wisdom). Sehingga itu kearifan-kearifan lokal yang ada pada setiap daerah perlu untuk dipupuk, dilestarikan sekaligus dipublikasikan agar dapat menjadi sumber dasar dalam pembentukan karakter bangsa Indonesia.

\section{Daftar Pustaka}

Abdullah, M. Amin. 2000. Dinamika Islam Kultural: Pemetaan Atas Wacana Keislaman Kontemporer (cetakan ke-1). Jakarta: Mizan.

Agus, Bustanuddin. 2009. Sosiologi Agama-1, Islam dan Pembangunan. Jakarta: Grafindo Persada. 
Amal, M. Adnan. 2002. Maluku Utara, Perjalanan Sejarah 1250-1800 (Jilid I dan II). Ternate: Universitas Khairun.

Ali, Muhammad Daud. 2011. Pengantar Ilmu Hukum dan Hukum Islam Indonesia (cetakan ke-16). Jakarta: Rajawali Press.

Ali, Zainuddin. 2008. Pengantar Ilmu Hukum Islam di Indonesia. Jakarta: Sinar Grafika.

Barry, David. 1982. The Principles of Sociology. London: Contstable.

Departemen Agama RI. 1982. Al Quran dan Terjemahannya. Jakarta: Proyek Pengadaan Kitab Suci al Quran Departemen Agama.

Departemen Pendidikan dan Kebudayaan RI. Tt. Adat Istiadat Maluku Utara. Jakarta: Ditjen kebudayaan RI.

Geertz, Clifford. 1981. Santri, Priyayi, Abangan dalam Masyarakat Jawa. Jakarta: Pustaka Jaya.

Husainy Abiy, Imam Muslim. Tt. Al Jamiu al Shahih. (Juz V-VI). Beirut: Daarul Fiqry.

Hasan, Abdul Hamid. 1987. Ternate dari Abad ke Abad. Ternate

Hartono H dan Arnicun Azis. 1997. Ilmu Sosial Dasar. Jakarta: Bumi Aksara.

Keraf, Gorys. 2010. Linguistik Bandingan Historis. Jakarta: Gramedia Pustaka Utama.

Koentjaraningrat. 1981. Beberapa Pokok Antropologi Sosial. Jakarta: PT Dian Rakyat.

Kuntowijoyo. 2001. Muslim Tanpa Masjid, Essai-Essai Agama, Budaya dan Politik dalam Bingkai Strukturalisme Transendental. Bandung: Mizan.

Liliwere, A. 2003. Dasar-Dasar Komunikasi Antar Budaya. Yogyakarta: Pustaka Pelajar.

Museum Negeri Siwalima. 1992. Sejarah Keraton Kesultanan Ternate (dari Foramadiahi kelima jero-jero). Ambon.

Malik, al Imam. 1348 H. Al-Muwaththa (Juz IV). Mesir: Musthafa al Baabil 
Halabiy.

Miles, Matthew B dan Huberman, A.Michael. 1992. Qualitative Data Analysis. Baverly Hill: SAGE Publication ltd.

Mudafar, Syah. Tt. Lingkungan Hidup Adat Ternate. Ternate Maluku Utara.

Poerwadarminta, WJS. 1989. Kamus Umum Bahasa Indonesia. Jakarta: Balai Pustaka.

Proyek Pengembangan Media Kebudayaan. 1985. Sekitar Tradisi Ternate. Jakarta: Ditjen Kebudayaan Departemen P dan K Republik Indonesia.

Rajiloen, L. 1983. Peristiwa Sejarah Tentang Adat Istiadat Daerah Moloku Kie Raha. Ternate

Sulaiman, M. Noor. 1995. Adat Segulaha dalam Perspektif Ajaran Islam Makalah Laporan Hasil Penelitian. Ternate: Fakultas Tarbiyah.

Sulaiman, M. Noor. 2001. Alkhairaat dan Perubahan Sosial Budaya Masyarakat Kaili. Jakarta: Pustaka Firdaus.

Sewang, Ahmad. 2005. Islamisasi Kerajaan Gowa Abad XVI sampai Abad XVII. Jakarta: Yayasan Obor Indonesia.

Sidik. 2011. Pandangan Masyarakat Muslim Kaili Terhadap Tradisi Balia di Palu: Suatu Analisis Teo Sosiologis. Disertasi. Makassar: Program Pascasarjana UIN Alauddin.

Tjandrasasmita, Uka. 1996. The Arrival and Expansion of Islam in Indonesia in Relation to Southeast Asia dalam Mulyanto Sumardi (ed), International Seminar on Islam in Southeast Asia. Jakarta: Lembaga Penelitian IAIN Syarif Hidayatullah.

Wahid, Abdurrahman. 2001. Pergulatan Negara, Agama dan Kebudayaan. Jakarta: Desantara. 